\title{
SCREENING THE RIGHT CANDIDATE
}

\section{The evolution of high-throughput screening technologies means that recruiters are looking for candidates who have expertise in many areas.}

When I sat down to write this article on careers in highthroughput screening (HTS), I began by doing what any writer (or indeed any scientist investigating a new subject) does, that is, looked for background articles to research the subject. But there seemed to be few articles written about careers in screening. One reason seems to be that HTS is a fairly recent discipline, and most people — usually those with a good biochemistry (in particular, experience with handling proteins and assays) or engineering background combined with process management skills - were recruited from other areas of industry. As screening technology is expensive, it is unlikely that academia will have these resources, and consequently there is very little awareness of the importance of screening in drug discovery in academic settings, being viewed by many as a tool, rather than a genuine scientific career.

Because of this, the world of screening is generally perceived as being similar to an automotive production line, in which machines continuously pump through as many compounds as possible to find promising hits that can be developed into drugs. To a certain degree, these perceptions are correct. Numbers have been the name of the game for companies in recent years, as the sheer quantity of targets produced by molecular biology in the early to mid-1990s drove companies to develop high-throughput technologies that would allow tens and even hundreds of thousands of compounds to be screened every day.

But, many companies are beginning to place less emphasis on numbers of compounds screened and are concentrating more on quality control, robustness and data mining. These companies are developing technologies and strategies that focus and filter their vast libraries of compounds to maximize the chances of obtaining the right hit (see the Review by Walters and Namchuck on page 259 of this issue). As a result, screening departments are becoming more creative in assay creation and development, and are evolving into dynamic, multi-disciplinary operations in which chemists, biologists and engineers work together to develop and optimize their screening tools.
So, will this affect the way companies recruit screeners? As before, a sound knowledge of biochemistry or engineering remains a strong selling point, together with a high degree of organizational skills and a good head for process management. But the skillset will change as technology progresses, says David Burns, Senior Project Leader of Biological Screening at Abbott Laboratories. "As well as having an interest in science, people need to be detail-orientated, innovative and creative - they have to have that spark. People need to know that what they have done will contribute to something in the long run."

"The general temperament of people who do well in screening is a mixture of innovation, curiosity and practicality, and you have to be results-orientated," says Paul Negulescu, Vice President of Discovery Biology at Vertex Pharmaceuticals. "You need to have a good understanding of the data, be able to translate data, filter information and understand types of cells and assays."

Christine Giordano, Executive Director of the Society for Biomolecular Screening (SBS; see BOX 1) agrees. “There's a fine art to conducting screening - it's not just turning the wheel and cranking things out. To be successful you need to have expertise in many areas: running assays, tracking and collecting data, and looking after machinery. You need to be able to understand and appreciate different areas."

Another important issue that the industry faces is where the next generation of screeners is going to come from. Few academic institutions provide the necessary skills or knowledge base, and in response to this, the SBS is creating academic research programmes (for example, at Western Michigan University in the United States and McMaster University in Canada) to bridge this gap. In the meantime, companies say that screeners tend to be recruited at the postgraduate level, and advise that a graduate or postgraduate who is interested in screening should seek internships and part-time work in industry to gain exposure to the process, and then integrate this experience with their course work.

Simon Frantz

\section{Box 1 | Further information on high-throughput screening}

Websites

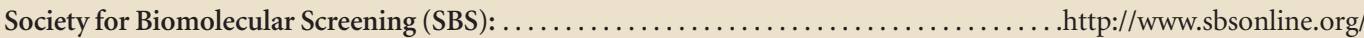
The SBS provides a forum for screeners, contains job listings and produces screening-based publications, including the Journal of Biomolecular Screening and SBS News.

Laboratory Robotics Interest Group: $\ldots \ldots \ldots \ldots \ldots \ldots \ldots \ldots \ldots \ldots \ldots \ldots \ldots \ldots \ldots \ldots \ldots \ldots \ldots \ldots \ldots \ldots$ http:/lab-robotics.org/ A US-based special interest group focused on laboratory automation, which has more than 7,000 scientist and engineer members. The group holds regional meetings each year to discuss members' experiences in automation.

The Association for Lab Automation (ALA): .http://labautomation.org/ A nonprofit organization with a membership of more than 1,300 scientists. The ALA organizes conferences, short courses and scholarship programmes, and also publishes the Journal of the Association for Lab Automation.

Further Reading

Smith, A. Screening for drug discovery. Nature 418, 451-463 (2002).

A useful introduction to screening, which also contains an extensive listing of relevant companies worldwide.

Editor (News), Nature Reviews Drug Discovery. email:s.frantz@nature.com 